\title{
PENGARUH BRAND IMAGE TERHADAP KEPUTUSAN KONSUMEN DALAM MEMBELI MOTOR HONDA MEREK GENIO (STUDI KASUS MASYARAKAT DESA RANTAU PANJANG KECAMATAN LAWANG WETAN)
}

\author{
Sri Gustini ${ }^{1}$, Paisal Subrata ${ }^{2}$ \\ 1 $\underline{\text { srigustini.mudrik@gmail.com }}$
}

STIE Rahmaniyah Sekayu, Sumatera Selatan, Indonesia

\begin{abstract}
ABSTRAK. Tujuan penelitian yang dilakukan adalah untuk mengetahui pengaruh brand image terhadap keputusan konsumen dalam membeli motor Honda merek Genio (Studi Kasus Masyarakat Desa Rantau Panjang Kecamatan Lawang Wetan). Metode penelitian yang digunakan adalah metode deskriptif kuantitatif. Teknik pengumpulan data yang digunakan adalah penelitian kuesioner, observasi dan studi dokumentasi. Analisis data dilakukan menggunakan uji validitas, uji reliabilitas, regresi linier sederhana, koefisien korelasi dan uji hipotesis (uji t).Hasil penelitian menunjukkan bahwa nilai korelasi variabel keputusan pembelian (r) sebesar 0,294. Dari penafsiran terhadap koefisien korelasi tersebut dapat diketahui bahwa terjadi hubungan positif yang tidak terlalu kuat atau sedangkan mempengaruhi keputusan pembelian. Sedangkan nilai $\mathrm{R}^{2}$ (R Sequare) sebesar 0,087 menunjukkan bahwa variabel brand image mempengaruhi keputusan pembelian sebesar 8,7 persen, sedangkan sisanya 91,3 persen dipengaruhi oleh variabel lain yang tidak diteliti dalam penelitian ini dan berdasarkan hasil uji hipotesis diketahuiada pengaruh brand image terhadap keputusan konsumen dalam membeli motor honda Merek Genio (Studi Kasus Masyarakat Desa Rantau Panjang Kecamatan Lawang Wetan).
\end{abstract}

Kata Kunci : Brand Image,Keputusan Pembelian

\section{PENDAHULUAN}

Kebutuhan terhadap alat transportasi sepeda motor yang meningkat, dapat menjadi peluang bagi perusahaan otomotif khususnya yang memproduksi sepeda motor, karena dengan produknya dapat memberikan solusi alternatif yang jitu bagi masyarakat untuk menunjang kegiatan sehari-hari. Meningkatnya kebutuhan seseorang terhadap sepeda motor tentu saja akan meningkatkan persaingan bagi perusahaan otomotif, karena setiap perusahaan berusaha untuk menguasai pangsa pasar dengan memenuhi keinginan dan kebutuhan konsumen, sehingga tujuan perusahaan akan tercapai. Usaha yang dilakukan oleh perusahaan otomotif tentu saja dengan berkompetisi untuk menciptakan produk sepeda motor dengan model dan jenis yang semakin beragam, dengan teknologi dan inovasi yang lebih baik dari sebelumnya. Selain itu, perusahaan juga dituntut untuk lebih aktif dalam 
mendistribusikan produknya serta mengenalkan kepada masyarakat agar dapat menarik minat konsumen untuk melakukan keputusan pembelian.

Menurut Kotler dan Amstrong (2013: 170), keputusan pembelian merupakan sikap seseorang untuk membeli atau menggunakan suatu produk baik berupa barang atau jasa yang telah diyakini akan memuaskan dirinya dan kesediaan menanggung resiko yang mungkin ditimbulkanya. Sedangkan menurut Supranto (2011: 211), memutuskan berarti memilih salah satu dari dua atau lebih alternatif membeli suatu produk/jasa. Meskipun sering merujuk tentang pemilihan antara obyek (barang, merek, toko / tempat berbelanja), konsumen sebenarnya memilih antara alternatif perilaku berkenaan dengan obyek tersebut. Adanya keputusan pembelian ini akan dipengaruhi oleh beberapa faktor yaitu promosi dan brand image.Menurut Kotler dan Keller (2013: 28), brand image adalah persepsi tentang merek seperti yang digambarkan brand assocition yang tersimpan dalam ingatan konsumen. Brand image dipilih karena berkaitan dengan citra, nama, dan brand image tersebut. Citra merek (brand image) suatu produk merupakan representasi dari keseluruhan persepsi terhadap merek dan dibentuk dari informasi dan pengalaman masa lalu terhadap merek itu. Pengaruh citra merek suatu produk berhubungan dengan keyakinan dan preferensi konsumen terhadap suatu merek produk. Konsumen yang memiliki citra positif terhadap suatu merek tertentu akan lebih memungkinkan konsumen tersebut untuk melakukan pembelian ulang dari produk-produk yang dihasilkan dari merek perusahaan tersebut.

Saat ini persaingan diantara perusahaan produk sepeda motor seperti Honda, Yamaha, Suzuki, Kawasaki, dan yang lainnya di Indonesia sangat ketat. Setiap perusahaan harus dapat meningkatkan inovasi baru terhadap produknya agar dapat memenuhi harapan bagi calon konsumen. Salah satu persaingan produk sepeda motor yang terjadi saat ini adalah sepeda motor matic, sepeda motor ini merupakan tipe sepeda motor otomatis yang tidak menggunakan operan gigi manual dan hanya cukup sekali akselerasi. Saat ini, tipe sepeda motor matic sangat digemari oleh masyarakat Indonesia, selain muda penggunaanya, juga mempunyai desain yang sangat ramping sehingga menjadi pilihan terutama untuk kaum wanita. Hal ini yang membuat produsen sepeda motor berlomba-lomba untuk memproduksi dan menawarkan sepeda motor jenis matic. 
Honda Genio merupakan motor skutik buatan perusahaan Honda asal Jepang yang memiliki nilai penjualan yang sangat fantastis. Semenjak pertama kali dikeluarkan oleh Honda, Motor Honda Genio ini langsung menjadi motor matic idola para penyuka motor matic khususnya para kaum hawa yang menginginkan sebuah motor yang simpel dan praktis untuk dikendarai. Dengan banyaknya peminat terhadap Honda Genio, tidak heran jika motor skutik Hondaini mendapatkan prestasi sebagai motor paling laris di Indonesia dalam beberapa tahun terakhir.Genio tersedia dalam dua pilihan, tipe CBS (comby brake system) dan CBS-ISS (idling stop system). CBS terkait dengan sistem pengereman yang terletak pada tuas rem kiri. Dengan menekannya, maka rem depan dan belakang bekerja otomatis. Sementara fitur ISS terletak pada area stang bagian kanan. Perangkat ini sudah umum terdapat pada model BeAT maupun Vario.Rumah kuncinya sudah ada alat pengaman dan tersedia pula tombol untuk membuka bagasi. Sedikit ke bawah, ada dua buah ruang penyimpanan barang cukup luas serta hooker (gantungan). Akomodasi barang bawaan juga didukung ketersediaan bagasi 14 liter. Pemilik dapat menyimpan tas kecil serta jaket maupun sarung tangan yang tipis.

Berdasarkan hasil wawancara Penulis dengan beberapa masyarakat pengguna motor metic Genio khususnya pada Desa Rantau Panjang Kecamatan Lawang Wetan, alasanya menggunakan motor metic merek Genio adalah karena kualitas motornya cukup baik dan ramah lingkungan, desain motor yang unik, irit bahan bakar dan pada saat berjalan motor tidak goyang atau melayang, motor metic Genio menyediakan soket power outlet untuk mengisi ulang baterai smartphone. Selain alasan tersebut, beberapa masyarakat menggunakan motor metic Genio juga dikarenakan motor metic Genio menurutnya sudah mempunyai citra merek yang baik, rata-rata masyarakat membeli motor tersebut atas rekomendasi keluarga, teman dan lingkungan disekitarnya. Dilihat dari harga yang di tawarkan perusahaan juga terjangkau dibandingan motor metic sejenisnya dan mudah didapatkan dari agen-agen atau dealer motor Honda selalu ada persediaan untuk penjualan motot metic Genio. 


\section{TINJAUAN PUSTAKA}

\subsection{Brand image (Citra Merak)}

Menurut Setiadi (2013: 180), citra merek (brand image) merupakan representasi dari keseluruhan persepsi terhadap merek dan dibentuk dari informasi dan pengalaman masa lalu terhadap merek itu. Citra terhadap merek berhubungan dengan sikap yang berupa keyakinan dan preferensi terhadap suatu merek. Konsumen yang memiliki citra yang positif terhadap suatu merek, akan lebih memungkinkan untuk melakukan pembelian. Sedangkan menurut Kotler dan Keller (2013: 28), brand image adalah persepsi tentang merek seperti yang digambarkan brand assocition yang tersimpan dalam ingatan konsumen.

\subsection{Peran Brand image}

Kotler dan Keller (2013:242), berpendapat bahwa sebuah merek memiliki beberapa peran, antara lain :

a. Merek memudahkan dalam proses pemesanan dan penelusuran suatu produk.

b. Merek membantu untuk mengatur persediaan dan pencatatan akutansi.

c. Merek menawarkan perlindungan hukum atas aspek atau keunikan produk yang dimiliki.

d. Merek menandakan suatu kualitas tertentu sehingga pembeli yang puas akan melakukan pembelian ulang.

e. Merek menjadi suatu sarana yang kuat untuk mengamankan keunggulan kompetitif.

\subsection{Faktor-Faktor Mempengaruhi Brand image}

Menurut Sutisna (2011: 80), menyatakan bahwa brand image memiliki 3 variabel pendukung, yaitu :

a. Citra pembuat/perusahaan (corporate image)

b. Citra pemakai (user image)

c. Citra Produk (product image)

Menurut Aaker (2012: 139), berpendapat citra merek terdiri dari tiga komponen yaitu : 
a. Product Attributes (atribut produk), yang merupakan hal-hal yang berkaitan dengan merek tersebut sendiri seperti, kemasan, isi produk, harga, rasa, dll.

b. Consumer Benefits (keuntungan konsumen), yang merupakan kegunaan produk dari merek tersebut.

c. Brand Personality (kepribadian merek), merupakan asosiasi (presepsi) yang membayangkan mengenai kepribadian sebuah merek apabila merek tersebut seorang manusia.

\subsection{Indikator Brand Image}

Menurut Shimp dalam Bastian (2014: 2), brand imagediukur dari 3 hal, yaitu :

a. Atribut

Atribut adalah ciri-ciri atau berbagai aspek dari merek yang diiklankan. Atribut juga dibagi menjadi dua bagian, yaitu hal-hal yang tidak berhubungan dengan produk (contoh : harga, kemasan, pemakai, citra penggunaan), dan hal-hal yang berhubungan dengan produk (contoh : warna, ukuran, desain).

b. Manfaat

Manfaat dibagi menjadi tiga bagian, yaitu fungsional, simbolis, dan pengalaman.

c. Evaluasi keseluruhan

Evaluasi keseluruhan, yaitu nilai atau kepentingan subjektif dimana konsumen menambahkannya pada hasil konsumsi.

Menurut Kotler dan Keller (2013: 29), indikator pembentukan citra merek adalah:

a. Keunggulan produk

Salah satu faktor pembentuk brand image, dimana produk tersebut unggul dalam persaingan. Karena keunggulan kualitas (model dan kenyamanan) dan ciri khas itulah yang menyebabkan suatu produk mempunyai daya tarik tersendiri bagi konsumen. Favorability of brand association adalah asosiasi merek dimana konsumen percaya bahwa atribut dan manfaat yang diberikan oleh merek akan dapat memenuhi atau memuaskan kebutuhan dan keinginan 
mereka sehingga mereka membentuk sikap positif terhadap merek, seperti : brand image, harga produk dan daya tahan produk.

b. Kekuatan merek

Asosiasi merek tergantung pada bagaimana informasi masuk kedalam ingatan konsumen dan bagaimana proses bertahan sebagai bagian dari citra merek. Kekuatan asosiasi merek ini merupakan fungsi dari jumlah pengolahan informasi yang diterima pada proses ecoding. Pentingnya asosiasi merek pada ingatan konsumen tergantung pada bagaimana suatu merek tersebut dipertimbangkan, seperti : reputasi produk, kejelasan informasi produk, daya saing produk.

c. Keunikan merek

Asosiasi terhadap suatu merek mau tidak mau harus terbagi dengan merekmerek lain. Oleh karena itu, harus diciptakan keunggulan bersaing yang dapat dijadikan alasan bagi konsumen untuk memilih suatu merek tertentu. Dengan memposisikan merek lebih mengarah kepada pengalaman atau keuntungan diri dari image produk tersebut. Dari perbedaan yang ada, baik dari produk, pelayanan, personil, dan saluran yang diharapkan memberikan perbedaan dari pesaingnya, yang dapat memberikan keuntungan bagi produsen dan konsumen, seperti : desain produk, warna produk, bentuk produk dan motif produk.

Berdasarkan pendapat Kotler dan Keller (2013: 29) di atas, maka indikator yang digunakan peneliti untuk mengukur brand image adalah :

a. Keunggulan produk, seperti : brand image, harga produk dan daya tahan produk.

b. Kekuatan merek, seperti : reputasi produk, kejelasan informasi produk, daya saing produk.

c. Keunikan merek,seperti : desain produk, warna produk dan bentuk produk dan motif produk.

\subsection{Keputusan Pembelian}

Menurut Kotler dan Amstrong (2013: 170), keputusan pembelian merupakan sikap seseorang untuk membeli atau menggunakan suatu produk baik 
berupa barang atau jasa yang telah diyakini akan memuaskan dirinya dan kesediaan menanggung resiko yang mungkin ditimbulkanya. Keputusan pembelian yang diambil oleh pembeli sebenarnya merupakan kumpulan dari sejumlah keputusan yang terorganisir. Ada lima tahap yang dilalui konsumen dalam proses pengambilan keputusan pembelian yaitu :
a. Pengenalan Masalah
b. Pencarian Informasi
c. Evaluasi Alternatif
d. Keputusan Pembelian
e. Perilaku Setelah Membeli

Menurut Kotler (2012: 163), keputusan pembelian adalah tindakan dari konsumen untuk mau membeli atau tidak terhadap produk. Oleh karena itu, pengambilan keputusan pembelian konsumen merupakan suatu proses pemilihan salah satu dari beberapa alternatif penyelesaian masalah dengan tindak lanjut yang nyata. Adapun faktor yang mempengaruhi perilaku konsumen dalam pengambilan keputusan pembelian adalah :

a. Faktor Kebudayaan

Faktor kebudayaan berpengaruh luas dan mendalam terhadap perilaku konsumen. Faktor kebudayaan terdiri dari:
1) Budaya
2) Sub-budaya
3) Kelas sosial

b. Faktor Sosial

Selain faktor budaya, perilaku seorang konsumen dipengaruhi oleh faktorfaktor sosial seperti :

1) Kelompok acuan

2) Keluarga

3) Status sosial

c. Faktor Pribadi

Faktor pribadi yang memberikan kontribusi terhadap perilaku konsumen terdiri dari :

1) Usia dan tahap siklus hidup 
2) Pekerjaan dan lingkungan ekonomi

3) Gaya hidup

4) Kepribadian

d. Faktor Psikologis

Pilihan pembelian seseorang dipengaruhi oleh empat faktor psikologi utama yaitu :

1) Motivasi

2) Persepsi

3) Pembelajaran

4) Keyakinan dan pendirian.

Berdasarkan pendapat Kotler dan Amstrong (2013: 170), di atas maka indikator yang digunakan penulis untuk mengukur keputusan pembelian konsumen dalam penelitian ini adalah :

a. Pengenalan masalah seperti : keyakinan dan media masa.

b. Pencarian informasi seperti : media internet dan prioritas.

c. Evaluasi alternatif seperti : desain dan keunikan.

d. Perilaku setelah pembelian seperti : harga dan pelayanan

\section{METODOLOGI PENELITIAN}

\subsection{Desain Penelitian}

Desain penelitian atau rangcangan penelitian harus disusun terlebih dahulu sebelum peneliti melaksanakan penelitian. Menurut Sanusi (2013: 13), menyatakan desain penelitian dapat dikategorikan sebagai berikut:

a. Desain penelitian deskriptif adalah desain penelitian yang disusun dalam rangka memberikan gambaran secara sistematis tentang informasi ilmiah yang berasal dari subjek atau objek penelitian.

b. Desain penelitian kausalitas adalah desai penelitian yang disusun untuk meneliti kemungkinan adanya hubungan sebab-akibat antar variabel.

c. Desain penelitian korelasional adalah desain penelitian yang dirancang untuk meneliti bagaimana kemungkinan hubungan yang terjadi antara variabel dengan memperhatikan besaran koefisien kolerasi. 
d. Desain penelitian tindakan adalah desain penelitian dengan bentuk rancangan penelitiandalam penelitiantindakan peneliti mendeskripsikan, menginterpretasi dan menjelaskan suatu situasi sosial pada waktu yang bersamaan dengan melakukan perubahan atau intervensi dengan tujuan perbaikan atau partisipasi.

e. Desain penelitian eksperimental adalah desain penelitian yang disusun untuk meneliti adanya hubungan kausalitas mengenai sikap tertentu antara kelompok yang diberi perlakuan dengan kelompok lain yang tidak dikenai perlakuan.

f. Desain penelitian grounded adalah desain penelitian yang disusun untuk membuat generalisasi empiris, menetapkan konsep-konsep, serta membuktikan dan mengembangkan teori.

Adapun desain dalam penelitian ini penulis menggunakan desain penelitian kausalitas yaitu desain penelitian yang disusun untuk meneliti kemungkinan adanya hubungan sebab-akibat antara variabel.

\subsection{Jenis dan Sumber Data}

Menurut Dachlan (2014: 18), dilihat dari Sumbernya data yang digunakan dalam penelitian ini adalah :

a. Data Primer

Data primer adalah data yang diperoleh penelitian secara langsung dari Sumbernya. Data yang dikumpul melalui kuesioner, wawancara, observasi langsung di lapangan, dan melalui eksperimen adalah contoh data primer.

b. Data Sekunder

Data sekunder adalah data yang diperoleh peneliti tidak secara langsung dari Sumbernya melainkan telah dikumpulkan oleh pihak lain seperti profil perusahaan, data pelanggan, jumlah karyawan dan lain-lain.

Adapun jenis dan Sumber data yang digunakan dalam penelitian ini adalah data primer.

\subsection{Vaiabel dan Operasionalisasi Variabel Penelitian}


Menurut Sugiyono (2012: 145), variabel penelitian adalah hal yang berbentuk apa saja yang ditetapkan oleh peneliti untuk dipelajari sehingga diperoleh informasi tentang hal tersebut. Maka variabel-variabel yang terkait dalam penelitian ini adalah:

a. Variabel bebas/independent (X)adalah variabel mempengaruhi atau yang menjadi sebab perubahannya atau timbulnya variabel dependent (terikat). Adapun varibel bebas/independent dalam penelitian ini adalah brand image $(\mathrm{X})$.

b. Variabel terikat/dependent (Y)merupakan variabel yang dipengaruhi atau yang menjadi akibat, karena adanya variabel bebas.Adapun varibel terikat/dependent dalam penelitian ini adalah keputusan konsumen (Y).

Dalam operasionalisasi variabel menjelaskan variabel penelitian, konsep teori yang mendasari variabel penelitian, indikator variabel, skala pengkuran dan isntrumen penelitian serta item pertanyaan. Operasionalisasi variabel diringkas dan disajikan dalam bentuk tabel seperti dibawah ini :

Tabel 1.Operasionalisasi Variabel

\begin{tabular}{|c|c|c|c|c|c|c|}
\hline No & $\begin{array}{c}\text { Variabel dan } \\
\text { Definisi Variabel }\end{array}$ & $\begin{array}{c}\text { Sub } \\
\text { Variabel/ } \\
\text { Dimensi }\end{array}$ & Indikator & $\begin{array}{l}\text { Skala } \\
\text { ukur }\end{array}$ & $\begin{array}{l}\text { Jlh } \\
\text { Perny }\end{array}$ & $\begin{array}{l}\text { No.Per } \\
\text { nyt }\end{array}$ \\
\hline 1. & $\begin{array}{l}\text { Brand image }(\mathrm{X}) \text { : } \\
\text { Brand image } \\
\text { adalah persepsi } \\
\text { tentang merek } \\
\text { seperti yang } \\
\text { digambarkan } \\
\text { brand assocition } \\
\text { yang tersimpan } \\
\text { dalam ingatan } \\
\text { konsumen } \\
\text { (Kotler dan } \\
\text { Keller, 2012: 28). }\end{array}$ & $\begin{array}{l}\text { a. Keunggulan } \\
\text { produk } \\
\text { b. Kekuatan } \\
\text { merek }\end{array}$ & $\begin{array}{l}\text { 1. Brand image } \\
\text { 2. Harga Produk } \\
\text { 3. Daya Tahan } \\
\text { Produk. } \\
\text { 4. ReputasiProduk } \\
\text { 5. Kejelasan } \\
\text { Informasi } \\
\text { Produk } \\
\text { 6. Daya Saing } \\
\text { Produk } \\
\text { 7. Desain Produk } \\
\text { 8. Warna Produk } \\
\text { 9. Bentuk Produk } \\
\text { 10. Motif Produk. }\end{array}$ & Likert & 10 & $\begin{array}{c}7 \\
8 \\
9 \\
10\end{array}$ \\
\hline 2. & $\begin{array}{l}\text { Keputusan } \\
\text { Pembelian (Y): } \\
\text { Menurut Kotler } \\
\text { dan Amstrong } \\
\text { (2013: 170), } \\
\text { keputusan } \\
\text { pembelian } \\
\text { merupakan sikap }\end{array}$ & $\begin{array}{l}\text { a. Pengenalan } \\
\text { masalah }\end{array}$ & $\begin{array}{l}\text { 1. Keyakinan } \\
\text { 2. Bahan Bakar } \\
\text { 3. Rekomendasi } \\
\text { Keluarga } \\
\text { 4. Media internet } \\
\text { 5. Media Masa } \\
\text { 6. Prioritas } \\
\end{array}$ & Likert & 10 & $\begin{array}{l}1 \\
2 \\
3\end{array}$ \\
\hline
\end{tabular}




\begin{tabular}{|c|c|c|c|c|c|c|}
\hline No & $\begin{array}{c}\text { Variabel dan } \\
\text { Definisi Variabel }\end{array}$ & $\begin{array}{c}\text { Sub } \\
\text { Variabel/ } \\
\text { Dimensi }\end{array}$ & Indikator & $\begin{array}{l}\text { Skala } \\
\text { ukur }\end{array}$ & $\begin{array}{l}\text { Jlh } \\
\text { Perny }\end{array}$ & $\begin{array}{c}\text { No.Per } \\
\text { nyt }\end{array}$ \\
\hline & $\begin{array}{l}\text { seseorang untuk } \\
\text { membeli atau } \\
\text { menggunakan } \\
\text { suatu produk } \\
\text { baik berupa } \\
\text { barang atau jasa } \\
\text { yang telah } \\
\text { diyakini akan } \\
\text { memuaskan } \\
\text { dirinya dan } \\
\text { kesediaan } \\
\text { menanggung } \\
\text { resiko yang } \\
\text { mungkin } \\
\text { ditimbulkanya } \\
\end{array}$ & $\begin{array}{l}\text { c. Evaluasi } \\
\text { alternatif }\end{array}$ & $\begin{array}{l}\text { 7. Desain } \\
\text { 8. Keunikan } \\
\text { 9. Harga } \\
\text { 10. Pelayanan }\end{array}$ & & & $\begin{array}{l}7 \\
8\end{array}$ \\
\hline
\end{tabular}

\subsection{Populasi, Sampel dan Teknik Pengambilan Sampel}

Menurut Sugiyono (2012: 116), populasi adalah gabungan seluruh elemen yang memiliki serangkaiaan karakteristik serupa, yang mencakup semesta untuk kepentingan masalah riset pemasaran. Populasi dalam penelitian ini adalah konsumen yang menggunakan motor metic Honda Genio pada Desa Rantau Panjang Kecamatan Lawang Wetan.

Menurut Sugiyono (2012: 116), Sampel merupakan sebagian dari jumlah dan karakteristik populasi. Menurut Malhotra (2012: 369), apabila populasi tidak diketahui merekomendasikan jumlah sampel minimal 5 kali dari jumlah item pernyataan yang terdapat dikuesioner. Indikator dalam penelitian ini 10 item pernyataan variabel bebas dan 10 item pernyataan variabel terikat. Total pernyataan dalam penelitian ini adalah 20 pernyataan, sehingga $20 \times 5=100$. Jadi jumlah sampel yang diambil dalam penelitian ini adalah 100 responden.

Adapun metode pengambilan sampel dalam penelitian ini dilaksanakan dengan menggunakan metode non-probability sampling (pengambilan sampel secara tidak acak) dengan menggunakan teknik pengambilan sampel purposive sampling (teknik pengambilan sampel dengan pertimbangan tertentu), dimana sampel dipilih yang berdasarkan karakteristik. Adapun karekteritik tersebut adalah:

a. Responden merupakan konsumen yang berdomisili di Desa Rantau Panjang Kecamatan Lawang Wetan. 
b. Responden adalah konsumen yang berusia 17 tahun keatas.

\subsection{Teknik Analisis Data}

\subsubsection{Teknik Analisis Data}

Adapun tahap-tahap analisis data yang digunakan adalah sebagai berikut :

\section{Uji Validitas}

Menurut Priyatno (2012: 16), uji validitas digunakan untuk mengukur sah atau valid tidaknya suatu kuesioner. Kriteria pengujian adalah sebagai berikut :

a. Jika $r$ hitung $\geq \mathrm{r}$ tabel (uji 2 sisi dengan sig 0,05) maka instrumen atau itemitem pertanyaan berkolerasi signifikan terhadap skor total (dinyatakan valid).

b. Jika $r$ hitung $\leq \mathrm{r}$ tabel (uji 2 sisi dengan sig 0,05) maka instrumen atau itemitem pertanyaan tidak berkolerasi signifikan terhadap skor total (dinyatakan tidak valid).

Menurut Priyatno (2012: 17), uji validitas dilakuan dengan membandingkan nilai $r$ hitung dengan $r$ tabel untuk tingkat signifikansi 5 persen dari degree of freedom $(\mathrm{df})=\mathrm{n}-2$, dalam hal ini $\mathrm{n}$ adalah jumlah sampel. Jika $\mathrm{r}$ hitung > r tabel maka pertanyaan atau indikator tersebut dinyatakan valid, demikian sebaliknya bila $r$ hitung $<r$ tabel maka pertanyaan atauindikator tersebut dinyatakan tidak valid.

\section{Uji Reliabilitas}

Menurut Priyatno (2012: 25), uji reliabilitas merupakan alat untuk mengukur suatu kuesioner yang merupakan indikator dari variabel atau konstruk. Suatu kuesioner dikatakan reliable atau handal jika jawaban seseorang terhadap pernyataan adalah konsisten atau stabil dari waktu ke waktu. Pengukuran reliabilitas dilakukan dengan cara one shot atau pengukuran sekali saja dengan alat bantu SPSS uji statistik Cronbach Alpha $(\alpha)$. Untuk pengambilan keputusan uji reabilitas bisa menggunakan batasan 0,6, menurut Sekaran dalam Priyatno (2012: 25), reabilitas kurang dari 0.6 adalah kurang baik, sedangkan 0.7 dapat diterima dan diatas 0.8 adalah baik.

\section{Regresi Linier Sederhana}


Analisis ini digunakan untuk mengetahui seberapa besar pengaruh variabel bebas yaitu brand image (X) terhadap variabel terikatnya yaitu keputusan pembelian (Y). Menurut Sunyoto (2013: 119), persamaan regresi linier sederhana adalah sebagai berikut :

$$
\mathbf{Y}=a+\mathbf{b X}+\mathbf{e}
$$

Keterangan:

$\mathrm{Y}=$ Variabel dependen (keputusan pembelian); $\mathrm{a}=$ Konstanta; $\mathrm{b}=$ Koefisien regresi; $\mathrm{X}=$ Variabel independen (brand image); e = error / variabel pengganggu.

\section{Uji Korelasi Sederhana}

Menurut Priyatno (2012: 34),uji korelasi merupakan besaran yang menunjukkan besarnya variasi variabel dependen yang dapat dijelaskan oleh variable independennya. Pedoman untuk memberikan interprestasi koefisien korelasiadalah :

a. Jika korelasi 0,0 sampai 0,199 hubungannya sangat rendah.

b. Jika korelasi 0,20 sampai 0,399 hubungannya rendah.

c. Jika korelasi 0,40 sampai 0,599 hubungannya sedang.

d. Jika korelasi 0,60 sampai 0,799 hubungannya kuat.

e. Jika korelasi 0,80 sampai 1,000 sangat kuat.

\section{Pengujian Hipotesis (Uji t)}

Menurut Priyatno (2012: 62), uji hipotesis adalah suatu metode pengambilan keputusan yang didasarkan dari analisa data. Adapun didalam pengujian hipotesis ada 2 cara untuk membuat penyataan yaitu dengan cara sebagai berikut :

a. Pernyataan Hipotesis $\mathrm{Nol}\left(\mathrm{H}_{0}\right)$ yaitu :

1) Jika pernyataan yang di asumsikam benar kecuali ada bukti yang kuat untuk membantahnya.

2) Jika selalu mengandung pernyataan 'ssama dengan', '’tidak ada pengaruh", tidak ada perbedaan'.

3) Dilambangkan dengan $\mathrm{H}_{\mathrm{O}}$

b. Penyataan hipotesis alternatif $\left(\mathrm{H}_{\mathrm{a}}\right)$ yaitu : 
1) Jika pernyataan yang dinyatakan benar jika hipotesis nol $\left(\mathrm{H}_{0}\right)$ berhasil ditolak.

2) Dilambangkan dengan $\mathrm{H}_{1}$ atau $\mathrm{H}_{\mathrm{a}}$

Menurut Priyatno (2012: 61) Uji t digunakan untuk menguji signifikansi hubungan antara variabel X dan Y, apakah variabel X (brand image) benar-benar berpengaruh terhadap variabel $\mathrm{Y}$ (keputusan pembelian). Untuk pengujiannya hipotesis dalam penelitian ini menggunakan taraf signifikan 0,05 dan 2 sisi. Hipotesis yang digunakan dalam pengujian ini adalah :

$\mathrm{H}_{\mathrm{o}}$ : Variabel-variabel bebas (brand image) tidak mempunyai pengaruh yang signifikan terhadap variabel terikat (keputusan pembelian).

$\mathrm{H}_{\mathrm{a}}$ : Variabel-variabel bebas (brand image) mempunyai pengaruh yang signifikan terhadap variabel terikat (keputusan pembelian).

Dasar pengambilan keputusan Priyatno (2012: 65). adalah dengan menggunakan angka probabilitas signifikansi yaitu :

a. Apabila signifikansi $\mathrm{t}<0,05$ atau $\mathrm{t}$ hitung $\leq \mathrm{t}$ tabel, maka $\mathrm{H}_{\mathrm{o}}$ diterima dan $\mathrm{H}_{\mathrm{a}}$ ditolak. Artinya tidak ada pengaruh brand image terhadap keputusan konsumen.

b. Apabila signifikansi $\mathrm{t}>0,05$ atau $\mathrm{t}$ hitung $>\mathrm{t}$ tabel, maka $\mathrm{H}_{\mathrm{o}}$ ditolak dan $\mathrm{H}_{\mathrm{a}}$ diterima. Artinya ada pengaruh brand image.

\section{HASIL DAN PEMBAHASAN}

\subsection{Pengujian Validitas}

Pengujian validitas selengkapnya dapat di lihat pada tabel 4.6 berikut ini :

Tabel 2. Hasil Pengujian Validitas

\begin{tabular}{|c|c|c|c|c|}
\hline No. & Variabel/Indikator & $\mathrm{r}$ hitung & $\mathrm{r}$ tabel & Keterangan \\
\hline \multicolumn{4}{|c|}{ Brand image $(\mathrm{X})$} \\
\hline 1 & item1 & 0,496 & 0,1966 & Valid \\
\hline 2 & item2 & 0,536 & 0,1966 & Valid \\
\hline 3 & item3 & 0,543 & 0,1966 & Valid \\
\hline 4 & item4 & 0,525 & 0,1966 & Valid \\
\hline 5 & item5 & 0,487 & 0,1966 & Valid \\
\hline 6 & item6 & 0,571 & 0,1966 & Valid \\
\hline 7 & item7 & 0,441 & 0,1966 & Valid \\
\hline 8 & item8 & 0,479 & 0,1966 & Valid \\
\hline 9 & Item9 & 0,521 & 0,1966 & Valid \\
\hline 10 & Item10 & 0,479 & 0,1966 & Valid \\
\hline
\end{tabular}




\begin{tabular}{|c|c|c|c|c|}
\hline No. & Variabel/Indikator & r hitung & $\mathrm{r}$ tabel & Keterangan \\
\hline & \multicolumn{4}{|c|}{ Keputusan Pembelian (Y) } \\
\hline 1 & item1 & 0,418 & 0,1966 & Valid \\
\hline 2 & item2 & 0,474 & 0,1966 & Valid \\
\hline 3 & item3 & 0,348 & 0,1966 & Valid \\
\hline 4 & item4 & 0,408 & 0,1966 & Valid \\
\hline 5 & item5 & 0,373 & 0,1966 & Valid \\
\hline 6 & item6 & 0,532 & 0,1966 & Valid \\
\hline 7 & item7 & 0,568 & 0,1966 & Valid \\
\hline 8 & item8 & 0,583 & 0,1966 & Valid \\
\hline 9 & Item9 & 0,512 & 0,1966 & Valid \\
\hline 10 & Item10 & 0,283 & 0,1966 & Valid \\
\hline
\end{tabular}

Sumber : Data primer (diolah), 2021

Dari tabel diatas terlihat bahwa korelasi antara masing-masing indikator terhadap total skor konstruk dari setiap variabel menunjukkan hasil yang signifikan, menunjukkan bahwa $\mathrm{r}$ hitung (Corrected Item-Total Correlation)> $\mathrm{r}$ tabel $(0,1966)$ Sehingga dapat disimpulkan bahwa semua item dinyatakan valid.

\subsection{Pengujian Reliabilitas}

Adapun hasil pengujian reliabilitas untuk masing-masing variabel yang diringkas pada tabel berikut ini :

Tabel 3. Hasil Pengujian Reliabilitas

\begin{tabular}{|c|c|c|c|}
\hline No. & Variabel & Alpha & Keterangan \\
\hline 1 & Brand Image $(\mathrm{X})$ & 0,718 & Reliable \\
\hline 2 & Keputusan Pembelian (Y) & 0,690 & Reliable \\
\hline
\end{tabular}

Sumber : Data primer (diolah), 2021

Berdasarkan tabel diatas terlihat bahwa uji reliabilitas dilakukan terhadap item pernyataan yang dinyatakan valid. Suatu variabel dikatakan reliabel atau handal jika jawaban terhadap pernyataan selalu konsisten. Jadi hasil brand image $(\mathrm{X})$ adalah sebesar cronbach alpa $=0,718$, dan $\operatorname{keputusankonsumen}(\mathrm{Y})$ adalah sebesar cronbach alpa $=0,690$. Diketahui nilai "Alpha Cronbach" lebih besar dari 0,60, yang berarti kedua instrumen dinyatakan reliable atau memenuhi persyaratan.

\subsection{Analisis Persamaan Regresi Linear Sederhana}


Analisis regresi digunakan untuk menguji hipotesis tentang pengaruh variabel independen terhadap variabel dependen berdasarkan estimasi regresi linear sederhana dengan program SPSS diperoleh hasil seperti tabel dibawah ini. Tabel 4.Hasil Analisis Regresi Linear Sederhana

\begin{tabular}{|c|c|c|c|c|c|c|}
\hline \multicolumn{7}{|c|}{ Coefficients $^{\mathbf{a}}$} \\
\hline \multirow{2}{*}{\multicolumn{2}{|c|}{ Model }} & \multicolumn{2}{|c|}{$\begin{array}{l}\text { Unstandardized } \\
\text { Coefficients }\end{array}$} & \multirow{2}{*}{$\begin{array}{c}\text { Standardized } \\
\text { Coefficients } \\
\text { Beta }\end{array}$} & \multirow[t]{2}{*}{$\mathrm{t}$} & \multirow[t]{2}{*}{ Sig. } \\
\hline & & B & Std. Error & & & \\
\hline \multirow[b]{2}{*}{1} & (Constant) & 27,183 & 2,546 & & 10,676 &, 000 \\
\hline & brand.image $X$ & 233 & 076 & 294 & 3,050 & 003 \\
\hline
\end{tabular}

Sumber : Data primer (diolah), 2021

Berdasarkan tabel diatas dapat diketahui persamaan regresi yang terbentuk adalah :

$$
Y=27,183+0,233 X
$$

Dari persamaan tersebut dapat dijelaskan bahwa :

a. Nilai Konstanta sebesar 27,183 menunjukkan bahwa jika brand image dianggap tidak ada (nol) maka keputusan pembelian sebesar 27,183.

b. Koefisien regresi variabel brand image (X) menunjukkan pengaruh positif sebesar 0,233 terhadap keputusan pembelian (Y). Koefisien regresi bernilai positif apabila nilai variabel brand image $(\mathrm{X})$ bertambah maka variabel keputusan pembelian (Y) bertambah.

\subsection{Analisis Korelasi}

Adapun untuk hasil perhitungan korelasi dapat di lihat dari tabel berikut:

Tabel 5. Hasil Uji Korelasi

\begin{tabular}{|l|r|r|r|r|}
\hline \multicolumn{5}{|c|}{ Model Summary } \\
\hline Model & R & R Square & $\begin{array}{c}\text { Adjusted R } \\
\text { Square }\end{array}$ & $\begin{array}{c}\text { Std. Error of } \\
\text { the Estimate }\end{array}$ \\
\hline 1 &, $294^{\mathrm{a}}$ &, 087 &, 077 & 4,990 \\
\hline \multicolumn{2}{|r}{ a. Predictors: (Constant), brand.image_X } \\
\hline
\end{tabular}

Sumber : Data primer (diolah), 2021

Berdasarkan tabel 4.9 maka didapatkan nilai korelasi variabel keputusan pembelian (r) sebesar 0,294. Dari penafsiran terhadap koefisien korelasi tersebut dapat diketahui bahwa terjadi hubungan positif yang rendah variabel brand image antara variabel keputusan pembelian. Sedangkan nilai $\mathrm{R}^{2}$ (R Sequare) sebesar 
0,087 menunjukkan bahwa variabel brand image mempengaruhi keputusan pembelian sebesar 8,7 persen, sedangkan sisanya 91,3 persen dipengaruhi oleh variabel lain yang tidak diteliti dalam penelitian ini.

\subsection{Uji Hipotesis (Uji t)}

Adapun pegujian hipotesis secara parsial dalam dilihat pada tabel berikut:

Tabel 6. Uji Hipotesis (Uji t)

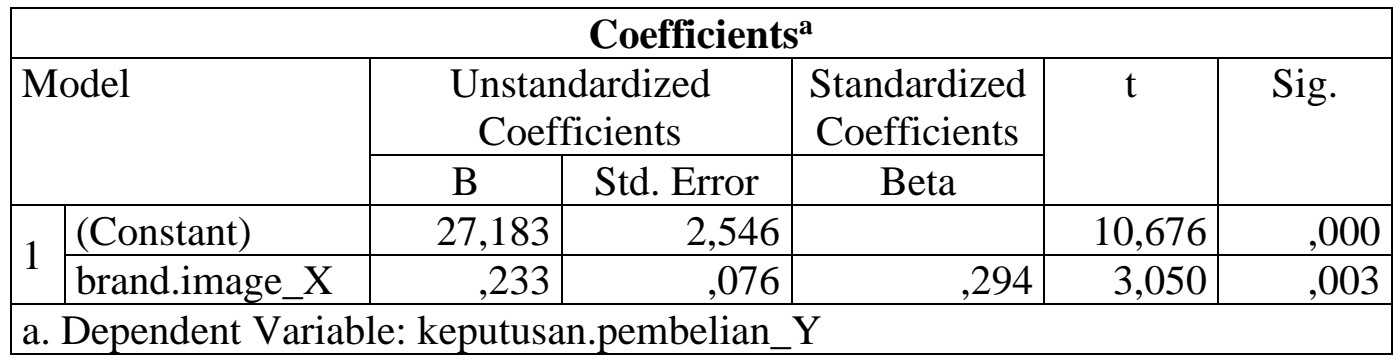

Sumber : Data primer (diolah), 2021

Berdasarkan tabel diatas dapat diketahui bahwa nilai thitung adalah 3,050 sedangkan $t_{\text {tabel }} 1,984$, oleh karena nilai $t_{\text {hitung }}>t_{\text {tabel }}$ yaitu 3,050>1,984, maka $H_{O}$ ditolak dan $\mathrm{H}_{\mathrm{a}}$ diterima. Artinya bahwa ada pengaruh brand image terhadap keputusan konsumen dalam membeli motor honda merek Genio (Studi Kasus Masyarakat Desa Rantau Panjang Kecamatan Lawang Wetan).

\subsection{Implementasi Hasil Penelitian}

Berdasarkan hasil uji hipotesis (uji t) didapakan nilai thitung adalah 3,050 sedangkan $t_{\text {tabel }} 1,984$, oleh karena nilai $t_{\text {hitung }}>t_{\text {tabel }}$ yaitu 3,050>1,984, maka $H_{O}$ ditolak dan $\mathrm{H}_{\mathrm{a}}$ diterima. Artinya bahwa ada pengaruh brand image terhadap keputusan konsumen dalam membeli motor honda merek Genio (Studi Kasus Masyarakat Desa Rantau Panjang Kecamatan Lawang Wetan).

Hasil penelitian ini mendukung hasil penelitian yang telah dilakukan Fransisca Paramitasari Musay, dengan judul Pengaruh Brand image Terhadap Keputusan Pembelian (Survei Pada Konsumen Kfc Kawi Malang). Berdasarkan hasil dari uji F, brand image yang terdiri dari citra perusahaan, citra pemakai, dan citra produk secara bersama-sama memiliki pengaruh yang signifikan terhadap keputusan pembelian. Hal ini dapat dibuktikan dengan nilai signifikansi 0,000 yang lebih kecil dari nilai probabilitas 0,05 sehingga Ho ditolak dan Ha diterima 
yang berarti bahwa hipotesis pertama dalam penelitian dapat dibuktikan kebenarannya.

Peneltian terdahulu yang juga dilakukan Yulismar, Tahun 2014, dengan judul penelitian pengaruh promosi terhadap keputusan pembelian konsumen pada Indrako Taluk Kuantan. Hasil pengujian uji t diketahui nilai signifikansi 0,000 $(0,000<0,05)$ maka Ho ditolak, artinya bahwa ada hubungan secara signifikan antara promosi dengan keputusan pembelian. Karena koefisien korelasi nilainya positif, maka berarti promosi berhubungan positif dan signifikan terhadap keputusan pembelian. Jadi dalam kasus ini dapat disimpulkan bahwa promosi berhubungan positif terhadap keputusan pembelian konsumen.

\section{SIMPULAN DAN SARAN}

\subsection{SIMPULAN}

Adapun simpulan dalam penulisan ini antara lain sebagai berikut:

1. Berdasarkan hasil uji regresi linear sederhana diketahui persamaan yang terbentuk adalah $\mathrm{Y}=27,183+0,233 \mathrm{X}$.

2. Berdasarkan hasil uji korelasi didapatkan nilai korelasi variabel keputusan pembelian (r) sebesar 0,294. Dari penafsiran terhadap koefisien korelasi tersebut dapat diketahui bahwa terjadi hubungan positif yang tidak terlalu kuat atau sedangkan mempengaruhi keputusan pembelian. Sedangkan nilai $\mathrm{R}^{2}$ ( $\mathrm{R}$ Sequare) sebesar 0,087 menunjukkan bahwa variabel brand image mempengaruhi keputusan pembelian sebesar 8,7 persen, sedangkan sisanya 91,3 persen dipengaruhi oleh variabel lain yang tidak diteliti dalam penelitian ini.

3. Ada pengaruh brand image terhadap keputusan konsumen dalam membeli motor honda merek Genio (Studi Kasus Masyarakat Desa Rantau Panjang Kecamatan Lawang Wetan).

\subsection{Saran}

Berdasarkan simpulan yang telah dikemukakan, maka dapat diajukan beberapa saran yaitu : 
1. Perusahaan harus mempertahankan brand image yang merupakan variabel tertinggi terhadap keputusan pembelian dalam terus bersaing dengan merek lain guna terus meningkatkan penjualan.

2. Hendaknya perusahaan memperbaiki lagi kinerja atau performance motor dan kualitas pelayana.

3. Bagi para peneliti selanjutnya, khususnya yang tertarik dan berminat untuk mendalami tentang brand image terhadap keputusan pembeliaan. diharapkan untuk mengembangkan penelitian ini dengan menambah sampel atau populasi yang lebih luas agar dapat menguji variabel lain yang diduga kuat dapat mempengaruhi keputusan pembelian seperti harga, promosi, brand imagedan lain-lain.

\section{DAFTAR PUSTAKA}

Aaker, David. A. 2009. Manajemen Ekuitas Merek, alih Bahasa; Aris Ananda. Edisi Revisi, J akarta:Mitra Utama.

Dachlan, Usman. 2014. Structural Equation Modeling. Semarang: Lentera Ilmu.

Fransisca, Paramitasari Musay. Pengaruh Brand image Terhadap Keputusan Pembelian (Survei Pada Konsumen Kfc Kawi Malang). Diunduh dari http://administrasibisnis.studentjournal.ub.ac.id/index.php/jab/article/down load/141/197 Tanggal 20 Juni 2020.

Kotler, Philip. 2012. Manajemen Pemasaran Analisis, Perencanaan dan Pengendalian, Jilid Dua. Jakarta: Erlangga.

Kotler, Philip dan Gary Amstrong. 2013. Manajemen Pemasaran. Jakarta: PT Prenhallindo.

Kotler, Philip dan Kevin Lane Keller. 2013. Manajemen Pemasaran. Jakarta:Indeks.

Malhotra, Naresh K. 2012. Riset Pemasaran. Edisi Empat. Jakarta: PT. Indeks.

Priyatno, Dwi. 2012. Mandiri Program SPSS. Yogyakarta: Mediakom.

Sanusi, Anwar . 2013. Metode Penelitian Bisnis. Jakarta: Salemba Empat. 
Setiadi,Nugroho J. 2003. Perilaku Konsumen Konsep dan Implikasi untuk. Strategi dan Penelitian Pemasaran. Jakarta: Prenada Media

Sugiyono. 2012. Metode Penelitian. Bandung: CV. Alfabeta.

Sunyoto. 2013. Metode dan Instrument Penelitian. Yogyakarta : CAPS

Supranto, J. Nandan Limakrisna. 2011. Statistika Ekonomi dan Bisnis. Jakarta: Mitra Wacana Media

Sutisna dan Pawitra. 2011. Perilaku Konsumen dan Komunikasi Pemasaran. Jakarta: PT. Remaja Rosdakarya.

Yulismar. 2014. Pengaruh Promosi Terhadap Keputusan Pembelian Konsumen Pada Indrako Taluk Kuantan. Diunduh dariHttp://EjournaS1.Undip.Ac.d/Index.Php/ Tanggal 20 Juni 2020 